\title{
The Nineteenth-century Theatres of Gábor Egressy and William Charles Macready
}

\author{
"Shakspeare is a good raft whereon to float \\ securely down the stream of time; fasten \\ yourself to that and your immortality is safe."
}

\section{BEFORE THE CURTAIN}

The thought of the present comparison between Macready's and Egressy's work onstage and off was inspired by two curious remarks. Firstly, that Macready's first fully restored King Lear was produced in 1838 the year when Egressy's was too. Secondly, in 1845 Gábor Erdélyi reported the way Macready acted Othello with the deliberate aim to present imitable foreign example to Hungarian actors. These two bits of information would be enough to spring a Hungarian Macreadyresearcher at immediate work, but there was a third impulse as well. Following the Hungarian war of independence in 1848-49 Jácint Rónay, once secretary to Kossuth and then emigrant in England, sent accounts of London theatre life back to Hungary for Egressy's theatrical journal.

Hence this paper will focus on the roughly contemporary intellectual milieux and theatres of William Charles Macready (1793-1873) in London and Gábor Egressy (1808-1866) in Pest-Buda and on the possible connections between them. It is not only their temporal parallel that prompts the present essay. Their equally perfectionist (indeed, difficult) personality, deep and expert fondness of

1 G. H. Lewes, "Macready," On Actors and the Art of Acting (1875), also in Victorian Dramatic Criticism, ed. George Rowell (London: Methuen, 1971), p. 86.

The AnaChronisT (2002) 129-150 ISSN 1219-2589 
literature and Shakespeare, and radiant personal power to shape public taste are what relate them. Their inexhaustibly energetic and also pioneering efforts in Shakespeare's cause, or Shakespeare's verse within what Dávidházi calls the "mystification" phase of the Cult gained both for them and their profession a long-awaited social respect. Both actors used their newly earned middle-class appreciation nobly, indeed, effectively, which furthered not only the art of the stage but the art of letters as well.

\section{THE BACKDROP}

By the nineteenth century the cult of Shakespeare, thanks to Garrick, had reached its full bloom in England, and the seeds were ready to be spread elsewhere. Indeed, bringing it home from England became a basic need for other countries.

Dobson, who views the matter from an English political angle, points out that not only America needed to take "steps towards appropriating the Bard in the interests of its own national and imperial project." ${ }^{3}$ Countries on the Continent realised that Bardolatry must become a part of the national literature at some point. It is no accident, says Dobson, that the adoration of Shakespeare was adopted with ardent enthusiasm after the Jubilee "by the next European country to experience a literate middle-class movement, Germany, (and thereafter by so many other emergent nations - Poland, Hungary, Czechoslovakia)." Dobson is quite right about the role of the "literate middle-class." The social groups that were to constitute the future Hungarian bourgeoisie nurtured the cult themselves, educated the public to become readers and audiences, set modern and quite high demands for the cultivators of the worship, even if the first morsels of the cult, the first experiences, were imported by aristocrats.

In Hungary it was mainly the members of the nobility, like Baron Wesselényi, Count Széchenyi, who read in foreign languages and had the means to travel abroad. But the editors and journalists who published or commented upon these travelogues in their magazines equally contributed to the appropriation of the Bard, and they all came from the middle-class(-to-be), Dávidházi's cultural anthropology points out. In this phase which Dávidházi calls

2 Péter Dávidházi, Isten másodszülöttje (Budapest: Gondolat, 1989).

3 Michael Dobson, The Making of the National Poet (Oxford: Clarendon Press, 1992), p. 228-229.

4 Dobson, p. 226-227 (my italics). (It would perhaps be less AnaChronistic of Dobson to refer to the Czech or Bohemian, etc. parts of the Habsburg Empire rather than to Czechoslovakia.) 
"initiation" to the cult, the Hungarian journals of the turn of the eighteenth and nineteenth centuries noted and highly praised the respect which the English expressed towards their scholars, poets and language, methods of maintaining and promoting the national literature, paralleled with an often urging, reprimanding overtone towards Hungarian upper classes who could have done more to import Shakespeare.

The news about the Jubilee and cult of Shakespeare ${ }^{5}$ was received with almost unanimous appreciation. Garrick's recipe, the national and institutionalised admiration of a poet offered ready means and methods for the cultural mission enthusiastic Hungarian men of letters and educators of men had sought. In the next phase, preceding true "institutionalisation" which Dávidházi describes as "mystification," a religious tone appears in Shakespearean discourse. On paying a visit to Shakespeare's birthplace the expressions of Hungarian pilgrims would rise to the heights of sacred adoration identifying Stratford with Bethlehem or even Mecca as our source Ronay did."

The new intellectual fashion in Hungary created a market for Shakespeare which $w a s$ most easily met by quick, careless translations from German versions of the plays. However, to the fortune of later generations, the rise of the literate middle class put an end to these pedestrian translations by firmly requiring higher standards and producing light winged texts. When in his Inditvány a szelleminonositás ügyében (1848) ${ }^{7}$ Egressy openly demands the poets of the highest ran' Arany, Petófi and Vorösmarty be honoured and financed by the nation to provide translations worthy of Shakespeare. Thus the lowborn actor, a prominent new member of the literate middle-class was in fact making the first steps towards institutionalising the Hungarian Shakespeare cult.

Macready's task, in the context of an apparently solidly established admiration of the Bard seems at first sight to have been rather different. The state of the cult in England can easily be characterised by a perfectly serious proposal

5 "Shakespearnak Jubileuma" [Shakespeare's Jubilee], Mindenes Gjüjtemény (1790), in Dávidházi, p. 96.

6 In 1864, Károly Szász, poet and Shakespeare translator, in his tri-centennial ode referred to Stratford as Bethlehem (Dávidházi, p. 143); while Jácint Rónay in the first edition of his Diary wrote with great simplicity "Stratford, Britannia Mekkája” [Stratford, Mecca of Britannia] (Dávidházi, p. 210).

7 [A Proposal for the Spiritual Nationalisation of Geniuses] Gábor Egressy, Életképek, Vol. V, 20 th February 1848. 
Macready recorded in his Reminiscences for erecting a monument to Shakespeare's mother. Macready's attitude was: "query, why not his grandmother?"

Often fluffed by brutality or explicit sexual references, the Restoration versions of Shakespearean pieces still popularly held the English stage. The programme of the Jubilee in fact featured none of the original Shakespearean plays. It appears that after Garrick no one ever read the original dramas apart from theatre-avoiding Romantics. Lamb's categorical refusal of having to see "an old man tottering about the stage with a walking-stick" ${ }^{\prime \prime}$ instead of his noble, visionary Lear is an obvious testimony against current stage versions. Thus it was left to a figure both devoted and famed, like Macready, to stop the adapters, Tate, Davenant, Colman, Dryden and the actor-managers clinging to Shakespeare's name rather than words and float on peacefully towards immortality or at least financial success. Our commercially mystified but generally unknown Author, degraded into the state of raw material or mere ingredient had to be saved from the tide. A Hamletian statement (though philologically untrue) would perfectly summarise the situation of the adapted plays, especially of King Lear: "it was never acted, or if it was, not above once - for the play, I remember, pleased not the million, 'twas caviare to the general.". Thus Macready's task appears to have been in a way similarly educational: redirect public attention and taste to their original object. His theoretical insistence on Shakespeare's words required completely new acting versions in practice.

Remarkably, both our restless heroes Egressy and Macready chose to dig out Shakespeare from underneath equally corrupt translations and adaptations, and create their own relatively pure Shakespearean text.

8 William Charles Macready, Macready's Reminiscences and Selections from his Diaries and Letters, 2 vols., ed. Sir Frederick Pollock, one of his executors. (London: Macmillan, 1875), Vol. I, p. 462.

9 Charles Lamb, "On the Tragedies of Shakespeare. considered with reference to their fitness for stage representation" (1811), also in Jonathan Bate, ed., The Romantics on Shakespeare (London: New Penguin Shakespeare Library, 1992), p. 123.

10 William Shakespeare, Hamlet, ed. Harold Jenkins, Arden edition third series (London: Routledge, 1982), p. 262, II.ii.431-3. 
WORDS, WORDS, WORDS

Relatively pure only, since Egressy did not manage to have a complete and professional Shakespearean translation and Macready did tailor Shakespearean lines.

Macready's first restoration, Richard III in 1823 proved unpopular with audiences who much preferred Cibber's version. Stubbornly enough, Macready did not give up. Despite the failure he soon started contemplation on restoring the text of other plays, ${ }^{11}$ King Lear among them. With this play, however, he took much care not to chase audiences away. In an experiment in 1834 he restored most of the text, yet following Tate's order in the storm scenes, and omitting the Fool. In later accounts he did not pride himself in this partial restoration though the greatness of the achievement and the significance of strategic progress is clearly indubitable. ${ }^{2}$

The restoration of King Lear in 1838 was probably Macready's greatest achievement. The extent of the changes in this play has been reported in many ways. Most sources, either contemporary or retrospective, applaud and appreciate the actor's efforts, and differ only in temper in doing so. One of them is the twentieth century theatre historian Odell, calm, omniscient and reliable, who after thorough examination found that the arrangement on the whole "follows Shakespeare's with great accuracy." "Hostile voices have been rare: it is always the mediocre contemporary actor, George Vandenhoff who is cited; whose nearly (in)famous sentence is the sole one which has represented the anti-Macreadian attitude ever since the late-nineteenth century. Of the 1838 restoration of King Lear Vandenhoff said in 1860 that Macready "restored as much of the text as suited him." ${ }^{14}$ Yet the production was and has ever since been widely celebrated as admittedly the first to include the Fool in one and a half centuries.

11 Macready's 1st restoration: Richard III (1S21), the 2nd one: Antony and Cleopatra (1833), the 3rd one: King Lear (without the Fool) (1834).

12 More on the 1834 production in Gabriella Reuss, "Veritas Filia Temporis or Shakespeare Unveiled? William Charles Macready's restoration of Shakespeare's King Lear in 1834 according to his unpublished promptbook," The AnaChronisT (2000), 88-101.

13 George C. D. Odell, Shakespeare from Betterton to Irving, 2 vols. (London: Constable, 1963, reprint of 1920), Vol. II, p. 195.

14 George Vandenhoff, Leaves from an Actor's Note-book, with reminiscences and chit-chat of the green. room and the stage, in England and America (New York, 1860), also in Robert Spraight, Shakespeare on Stage. An Illustrated History of Shakespearian performance (London: Collins, 1973), p. 74. 
As it is clear from his promptbooks, ${ }^{15}$ Macready's changes concerned mainly the length of the parts spoken, which, as the usual practice of theatres, is quite forgivable; or, as in the case of King Lear, the order of certain scenes, not the words of Shakespeare.

In fact, Macready followed the living tradition established by Garrick and continued (and carried to excess) by Kemble and Kean to cut Act One short after the Curse which had been the greatest "peak" in the play for all Lears. Lear thus gains an impressive exit after the ariatic monologue at Goneril's expense. The other point of more serious change was the storm in which Macready did not dare to straighten out the Tatean scene order. The core of it is that Macready followed Tate in joining the Shakespearean Act III Scenes 5 and 7 in one, supposedly for practical reasons, namely, to avoid another quick scene change. However, at least he exchanged all of Tate's bombastic or explanatory expressions for Shakespeare's own and included parts for the Fool. Hence the result, despite Vandenhoff's accusations, is obviously more Shakespearean than not, while familiar enough to prove capable of catching the audience's favour.

As Macready, Egressy was also curious about the original text, or about the closest access to it. In a way, Egressy too returned to Shakespeare's words when his production demanded a new translation from English. The way to it, however, was not paved; thus he had detours of a different kind.

Having Shakespeare in Hungarian, and later, having Shakespeare played in a manner worthy to the Bard, as organic parts of mystification, soon equalled a higher degree of civilisation and refinement of taste. Out of the twenty-two plays by Shakespeare appointed for translation in 1831 by the Academy, then the Magyar Tudós Társaság, ten (!) were produced in the following one and a half decades. According to Kerényi, “ebben nagy szerep jutott a színészi kezdeményezőkészségnek. Egressy és Megyeri az átlénỵegülés nagy lehetôségeit találták meg szerepeikben." 16

The first Shakespearean translation from English, was Macbeth, in prose, was made as early as 1812, however, this venture by Gábor Döbrentei had not

15 For the restoration of King Lear in 1834, see the promptbook held by the Bodleian Library, Oxford. For the 1838 production see the promptbook preserved in the Forster Collection, National Art Library, Victoria \& Albert Museum, London.

16 [This was due to a large extent to the initiative taken by the actors themselves. Egressy and Megyeri found great possibilities for identification in their Shakespearean parts.] Imre Kerényi, "A nemzeti romantika színháza," A Nemzeti Színház 150 éve, ed. Ferenc Kerényi (Budapest: Gondolat, 1987), p. 23. The great comic actor of the time, Károly Megveri was the first Hungarian Falstaff. 
invoked much response. It took nearly three decades for his pioneering view to work from the original rather than a German translation, came into fashion. In 1830 Döbrentei updated his Macbetb: re-translated it, this time in iambic verse and published it in an independent volume accompanied by, as Dávidházi appreciates, "az angol szakirodalom elmélyült ismeretéről tanúskodó kísérőtanulmányokkal körítve." ${ }^{17}$

Significantly, Egressy selected Döbrentei's work as an example to follow, and eventually managed to bring Shakespeare's rather than Schröder's Sturm und Drang style Lear onto the Hungarian stage. Egressy knew Shakespeare's play only from German translations and there had been only one model, again a German speaking one before him. In the winter of 1836-37, ignorant of the fact that he was to be contracted by the opening Hungarian Theatre of Pest and driven purely by his professional curiosity, he managed to reach Vienna in quite an adventurous fashion (thanks to his overt poverty) where he saw the famous actor Anschütz in the Burgtheater production of King Lear. So much different from that of the itinerant actors, the refined style of the Austrian artists, especially that of Anschütz impressed him deeply. He started preparing in mind for the title role, but the basis for such study was still missing. The lack of a playable text was recognised by Vörösmarty in 1837 in an overtly bitter tone:

Azon darabok közôl, melyek más nemzeteknél a színház örökös díszei, melyekben magokat jeles színészek vetekedve gyakorolják s a közönség csüggedetlen részvétele mellett kituntetik, alig bírunk egyet-kettoot jó fordításban. Nincs Learünk, nincs Romeónk; nem láthatjuk a Velencei Kalmárt, Hamletnek csak árnyékát bírjuk; [... ] pedig csak ilyen darabokban mutatja ki magát a szinész erejének tcljes nagy ságában, ily elmemũveken gy akorolhatja magát haszonnal. śrhetik valódi müvésszé. ${ }^{18}$

17 [Accompanied by studies betraying thorough knowledge of English secondary material.] Dávidházi, p. 107.

18 [Of those plays which are the everlasting ornaments of theatre for other nations, in which actors of greatest renown practise and excel themselves competing before the untiring attendance of the audience, scarcely do we possess one or two in good translation. We have no Lear, no Romeo; cannot see The Merchant of Venice and possess only a shadow of Hamlet [...] although only in this kind of plays can an actor show his full power, only in this kind of works of the mind can he practise himself with use and ripen himself a mature artist.] Mihály Vörösmarty, criticism on the performance of Schiller's Die Räuber at the Hungarian Theatre of Pest, dated September 18, 1837, in Mihály Vörösmarty, Drámák, elbeszélések, bírálatok, Magyar remekírók series, ed. András Martinkó (Budapest: Szépirodalmi Könyvkiadó, 1974), p. 676. 
The picture of the learned and learning artist apparently coincided with the aims and nature of both stars. As Macready, Egressy was not contented either with the texts currently available. From this time two unpublished but played acting versions are known due to Bayer's and Kiss's researches; but Egressy threw away both. One of them was, "Hérószi Szomorú Játék 5 Felvonásban Shakespeare és Schiller után, készült 1811 februáriusában” as Zsuzsánna Kiss found, ${ }^{19}$ while the other was probably translated by a touring company director. ${ }^{20}$

Egressy rather chose to adopt the comparative practice Döbrentei followed, when beside the original, he used Voss's, Burger's and Schiller's German versions as well. The censored promptbook frontispiece reads "Az eredeti, Schlegel és Petz után fordították Vajda, Jakab, Egressy." spoke German, Péter Vajda mastered English and Egressy supervised and coordinated the work paying special attention to his role which, in turn, was translated in iambs by Vajda for him.

Érdekes véletlen, hogy az elsố eredetiböl forditott magyar Lear-bemutatóra és az 1606-os elôadás utáni legelsõ teljes, csonkitatlan Lear-elōadásra Angliában egyazon évben, 1838-ban kerül sor. ${ }^{22}$

Like Macready's production four months earlier, ${ }^{23}$ it received a warm welcome. The title role remained one of the most popular and best "impersonated" roles of both actors (on this even the most hostile critics agree), who, true to their nature, never stopped refining themselves in it. Forster wrote in The Examiner: "Mr Macready has now, to his lasting honour, restored the text of Shakespeare [... ] Mr Macready's success has banished that disgrace from the

19 [A Heroic Tragedie in 5 Acts after [not by] Shakespeare and Schiller, written in Februarius, 1811] Zsuzsánna Kiss, A Lear király magyar forditásainak szöveg. és szinpadtörténeti vizsgálata, unpublished PhD thesis (Budapest: ELTE, 1997), p. 51.

20 According to Bayer, Ferenc Komlóssy's text is dated 1819. In József Bayer, Shakespeare drámái hazánkban, 2 vols. (Budapest: Kisfaludy Társaság Könyvtára, 1909), Vol. II, p. 275.

21 [Translated from the original, Schlegel and Petz by Vajda, Jakab, Egressy] Kiss, p. 79. The Hungarian Lipót Petz translated the play from English to German(!) and the raw material was the Warburton cdition of King l.car. Pct\%'s translation is "formahü, pontos, valódi irodalmi érték" |true to the original form, punctual, indeed a valuable piece of literature]. Kiss, p. 73.

22 [Interestingly enough, the debut of King Lear translated from the original took place in the very same year as the first full, untruncated production of Lear after 1606 in England.] Kiss, p. 76.

23 Macready's production took place 25th January 1838. 
stage for ever." ${ }^{24}$ Egressy's effort was quite similarly appreciated. In the following passage by Imre Vahot the nearly religious tone of mystification will also betray itself: "Shakespeare Learjét a nagy költô egyik legbuzgóbb tisztelôje, sôt, mũvészi dicsőitổje, Egressy Gábor hozá legelöször színpadunkra. E tettéért legy en áldott az ö neve!" 25 Toldy's opinion is also positive: "A fordítás helyenként darabos, de általában véve mégis az eredetinek erejét megközelítô, s ügy es kéz mũve. A király szerepe jambusokban." ${ }^{26}$

On the formation of the role Archer, an eyewitness-biographer says of Macready that

in Lear he found ample scope for [... subtlety of psychological suggestion which was one of his great qualities. He marked the gradual encroachments of insanity by the most delicate touches; and the irresistible tenderness of the last act contrasted beautifully with the overwhelming vehemence of the first and second. ${ }^{27}$

Even if we coolly replace all the superlatives with their basic forms in this obviously partial account we will see the main direction of Macready's impersonation of the character. His display of domestic gentility is widely appreciated even by the most hostile critics of the age. Archer's description refers to two other important points as well. First, that Macready's Lear was much less ariatic than any of his predecessors as he carefully designed graduality and credibility of all psychological changes. Second, that in his interpretation, as both the critics and his Diary refer to it, he is reluctant to display the Lambian image of the physically weak old man tottering with a stick. Rather, he depicted an energetic, vigorous old fellow with red cheeks and dominating, loud voice.

24 John Forster, "Macready's production of King Lear," The Examiner, February 4, 1838. Also in Dramatic Essays by John Forster and George Henry Lewes, eds. William Archer and Robert W. Lowe (London: Walter Scott Ltd 1896), p. 50.

25 [Shakespeare's Lear was first brought to our stage by a most enthusiastic admirer, indeed, the artistic worshipper of the poet, Gábor Egressy. For this deed, bless'd be his name!] Imre Vahot, "Lear király," Regélö, April 14th, 1842. Also in Magyar Shakespeare Tükör. Esszék, tanulmányok, krittkák, eds. Sándor Maller and Kálmán Ruttkay (Budapest: Gondolat, 1984), p. 130.

26[The translation is not round occasionally but in general it comes close to the power of the original and is the work of a skilled hand. The king's role in iambs.] Ferenc Toldy, Athenaeum, May 5 th 1838, The idea of looking at this particular piece of criticism came from Zsuzsánna Kiss. 27 William Archer, William Charles Macready, Eminent Actors series. (London: 1890), p. 203. 
The only thirty-year-old Egressy, fifteen years Macready's junior in the title role was also highly praised, even by critics like Toldy and Vahot who had had the opportunity to see Anschütz's Lear in Vienna. Vahot wrote:

Egressy mint Lear, kivéve az erôscbb indulatok és szenvedélyek kifejezését, Anschützcel sok tekintetben kiállja a versenyt, sõt azt vettem észre, hogy õ az öregséget testhordozásában hivebben tünteti vissza, s azon jelenetben is, midön Lear Cordeliát megismerve, ez elött térdre esik, s bũnbánólag beszél, hajlandó vagyok Egressy nek nỵu újtani az elsôség babérját. ${ }^{28}$

Interestingly, it is Egressy's domesticity and tenderness that moves the critic's heart the most, which fact undoubtedly strengthens the invisible string that relates the two actors. The passages quoted suggest that even if neither of the actors was too kingly or heroic, these momenta being absent from all the descriptions; with their empathy, analytic mind and psychological studies they mastered the personal or natural touches which caught their contemporaries' attention. Apparently, their life-size Lears brought the character closer to the audiences.

\section{THE WORLD AND THE STAGE}

A deeper look into the Hungarian and English intellectual context in the 1830s will explain more of the curious and seemingly occasional similarities between the two actors. Indeed, further ones will pop up, I found. Not only their personalities, interests and maximalism but their consciously chosen and developed style, way of interpretation, views on their profession and even their social position and impact have resemblances.

Unlike Kean, Macready never went on stage illuminated by alcohol, never led a Bohemian life, never left his partners' parts unread... and of course was never adored so ardently in unison. In short, he was eminent; that is, a sober and staid member of respectable society.

In rather an un-actor-like way he owned a house with flowery garden in the calm village of Elstree near London from where he took the trouble of

\footnotetext{
28 [Egressy as Lear, except in the expression of stronger emotions and passions, stands in many respects the competition with Anschütz, indeed, I noticed that he [Egressy] reflects old age by stature more faithfully, and in the scene in which recognising Cordelia he falls onto his kneels and speaks full of regret, I am willing to give the laurels of priority to Egressy.] Imre Vahot, "Lear király," Regélö, April 14th, 1842. Also in Maller \& Ruttkay, p. 130.
} 
commuting to work and lived there in peace with his lawful wedded wife and over half a dozen children, reading and preparing indefatigably. According to Macready's Diary, ${ }^{29}$ the actor's reading varied on quite a wide scale: from Austen, Byron, Thackeray, Fielding, Rousseau, Voltaire and Racine etc to the classical authors (Livy, Homer, Virgil are often mentioned) whom he certainly read in their original tongues as his partbooks are usually full of Latin and Greek marginalia. He thought and talked his parts over with his wife, an actress herself, and more importantly, with his friends. The dinner parties the Macreadys threw as the Diary and Archer's biography tell us, saw many a reputed man of letters and artists of the age: the Wordsworths, Charles Lamb, William Wallace (his literary adviser) to mention some of the earlier friends. The young generation was represented by J. H. Reynolds, Lord Edward Bulwer-Lytton, Talfourd and Browning. Dickens and Forster were always regulars. Westland Marston complements the list with the names of Tennyson, Thackeray, Stanfield, Maclise, Etty, David Roberts, remarking that the guests' "very presence was a testimony to the intellect and cultivation of their host. It may be said" continues Marston, who himself gave Macready his first play to read, "that few had obtained any marked reputation in literature or art without making his [Macready's] acquaintance." 30

The phenomenon, the highly cultured actor as an active and reputed member of the learned circles, who attempted to contradict the great Romantics and played the unactable play of the mind, was at the time unique enough to attract attention. It is then not surprising that Macready sought and received sufficient encouragement from his learned friends when he initiated his Shakespearean restorations. When he was planning his first restoration of King Lear in 1834 in the last minute, although having Forster's strong support throughout, before making the promptbook he "Called on Reynolds [...] who approved of Lear with Shakespeare's text." ${ }^{31}$ The pledge of mutual respect and cooperation between theatre and contemporary literature seems to have been the actor's person, especially, when the common goal was the reintroduction of expunged texts to the audience.

Finding descriptions of Egressy roughly corresponding with those quoted above of Macready was not a difficult job at all. Staud's remark is practically an

29 William Charles Macready, The Diaries of William Charles Macready, 2 vols., ed. William Toynbee (London: Chapman and Hall, 1912).

30 Westland Marston, Our Recent Actors, 2 vols. (London, 1888), Vol. I, p. 61.

31 Macready, The Diaries, Vol. I, p. 129, dated May 3rd. 
equivalent of Marston's. Egressy's “Barátai korának legtehetségesebb emberi közül kerülnek ki." ${ }^{32}$ However, we must not expect fancy dinner parties at the Egressys: the actor who in fact made his way to the Burgtheater from Pest-Buda on foot to see Anschütz, lived with his fragile young wife, an actress herself, and their three children on rather moderate means, renting a small flat near the theatre over a chemist's.

In Hungary, perhaps due to the poverty of individuals, the circles of the intelligentsia met in inns rather than in private homes. Attempting to list Egressy's friends we find that critics like Bajza and Henszlmann who were most fierce opponents in the columns of magazines, frequented the very same circle at the inn Csiga. A prominent regular of the Csiga and later translator of the first full, and ever since most nobly and poetically phrased King Lear, Vörösmarty essayed on Shakespearean dramaturgical matters with just as great care as he taught correct English and Hungarian pronunciation on a linguistic basis in his criticisms. As chief editor of the Athenaeum, he gave space in his magazine for the ardent talks that stormed around Egressy's acting.

As Macready's "natural" style caused debates among viewers and reviewers throughout his career, Egressy's style stirred critical aesthetic discourse as well. The discussions of his style were paralleled by arguments on the reception of Shakespeare.

"An idealist Hegelian," ${ }^{33}$ sharp-penned Bajza ${ }^{34}$ was convinced that nature or reality should never be presented as they are, rather, in a beautified way. "Forditani klasszikai múveket hiven kell ugyan, de szinpadon előadni nem mindig lehet, és Shakespeare-t nevezetesen hüség rovására kockáztatni, mũveitől elidegeníteni a magyar közönséget, nem okosság." ${ }^{35}$ Hence Bajza expected Egressy

32 [His friends came from among the most talented people of his age.] Géza Staud, "Egressy Gábor," Nagy magyar szinészek, eds. Miklós Gyárfás and Ferenc Hont (Budapest: Gondolat, 1957), p. 95.

33 Béla Várdai, "Egressy Gábor mint Shakespeare-színész," Magjar Shakespeare Tár, Vol. II, No. 3 (Budapest: 1909) 1-120, p. 7.

$34 \mathrm{He}$ was the first director of the Hungarian Theatre of Pest, founder of several critical journals (e.g. Külföldi játékszín which was meant to publish foreign plays or Kritikai lapok which was first to publish regular criticisms). He also fathered the custom of publishing both regular literary and theatrical reviews. See also the Introduction by László Négyesy to Bajza József munkái, ed. L. Négyesy, Remekírók series (Budapest: Wodianer és Fiai, 1908).

35 [The translation of classical works must be done faithfully to the text but the performance on stage is not always possible; and risking Shakespeare by preferring faithfulness, and thus alienating the audience from his works is not a clever thing to do.] József Bajza, "Othello," Athenaeum, November 22nd, 1842. Also in Maller \& Ruttkay, p. 112. 
to sweeten his harsh style with a pinch of idealisation. Egressy answered in a dialogical pamphlet in which he refused being "nice" and stood for the characteristic and the real. Art historian Henszlmann joined the debate on the actor's side ${ }^{36}$ arguing that in understanding Shakespeare

közönségünk egy év óta nagyot haladt [... Építsünk bár [...] nagyobb színházat, [...] lássuk el azt csupa MacReadyk, Rachelek, Seydelmanok és Garrickekkel, [...] képezzük bár drámaíróinkat merô Shakespeare-ekké, [... ] s mégsem lesz nemzeti színházunk mindaddig, míg a közönség öneszmélkedésre nem szokik, mig a kritika egyesült eróvel azt ezen öneszméletre nem ösztönzi. ${ }^{37}$

Being a much more private person, Macready never wrote pamphlets explaining his style. However, we may trace a similar approach confessed to his Diary. In one of the rare moments when he was content with his performance he wrote "I felt myself the man." One of his main goals was not to "represent," as then was said, implying a distance between the actor and his piece declamation followed by bows and applause within a play. Rather, he meant to identify with the character all the time while on stage. He wasted no word and no effort whatsoever on beautification or idealisation.

Whether sympathetic or not, sources quite agree on the main features of Macready's acting. Downer mentions a contemporary critic in The Theatrical Times who found that "If Kean were the Byron of actors, Macready may in many respects afford a parallel to Wordsworth... [in particular, his] insight into the laws of nature under its varied modifications." Being less sweepingly passionate and

36 Imre Henszlmann, "Othello," Regile, November 20th, 1842, Also in Maller \& Ruttkay, pp. 122-

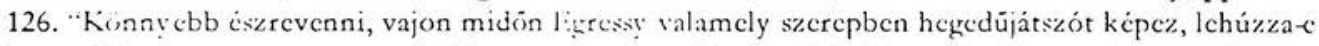
kestỵüut vagy ncm, s mo\%gásai itt vagy amott clég kerekdedek valának-c - mint a múvészet legbcisoibb mühly cbe behatni" [It is easier to note, when Egressy represents a violinist's solo in a part, whether he takes off his glove or not, whether his movements here or there are round enough or not - than to get to the innermost workshop of art.] Henszlmann, "Othello," also in Maller \& Ruttkay, p. 125.

37 [Our audiences have progressed a lot. [...] Let [...] an even larger theatre be built, [...] supply it with all MacReadys (sic!), Rachels, Seydelmans and Garricks, [...] train our playwrights all Shakespeares [... ]: yet we will not have a national theatre till the audience gets used to awareness, till they are encouraged and helped by critical discourse.] Imre Henszlmann, "Othello," Regélö, November 20th, 1842. Also in Maller \& Ruttkay, p. 123.

38 Macready, The Diaries, Vol. I, p. 192, dated October 25th, 1834.

39 The Theatrical Times, II. 1847, p. 164. Also in Alan S. Downer, The Eminent Tragedian W. C. Macready, (Cambridge, Mass.: Harvard University Press, 1966), p. 354. 
much more intellectual than Kean, also less "stately" than Kemble and even more industrious and analytical, Macready was constantly balancing and synthesising spontaneous and conscious acting. It is not surprising then, that many an experienced theatregoer missed the usual pathos, or, as Horne did, accused him of reading poetry "very badly" for he broke up poetry according to sense (sic!) and mood rather than to music. Certainly Horne admits that Macready was still very impressive, "because he is thoroughly in earnest." ${ }^{40}$ Another respected eyewitness reaches a very similar conclusion: "in all the touching domesticities of tragedy he is unrivalled," says Lewes. "But he fails in the characters which demand impassioned grandeur, and a certain largo of execution. His Macbeth and Othello have fine touches, but they are essentially unheroic." +1 Thus Macready redefined what was expected from tragedians and opened the way before a more realistic or "natural" style of acting.

Macready's unusual way of identification, his unheroic Macbeth and humansized Othello impressed János Erdélyi when he saw him act in Paris in 1844 . He wrote to Pesti Divatlap openly setting Macready's example before Hungarian actors and spectators:

Ha Egressy Gábor most volna Párizsban, sok hasznát vehetné azon stúdiumoknak, melyeket Macready játékából meríthetni. [...] a közönség is csak elmegy színházba, de mint az iskolás gyerek, könyrvel a kezében, Robertson úr fordítása szerint olvasván a színészek után Shakespeare-t, s ez csak fele haszon, mert a színészet elvesz, s pedig minô élv a szinészettel! ${ }^{42}$

40 R. H. Horne, A New Spirit of the Age, 2 vols. (London: 1844), Vol. II, p. 115.

41 G. H. Lewes, "Was Macready a Great Actor?" in Dramatic Essays by John Forster and George Henry Lewes, ed. William Archer and Robert W'. Lowe (London: Walter Scott Ltd, 1896), (London: Walter Scott Ltd, 1896), p. 130.

42 [If Gábor Egressy were in Paris now he could make much use of those lessons which Macready's acting provides. [...] and the audience attend the theatre, like schoolchildren, with books in hands, reading Shakespeare following the actors in Mr Robertson's translation. And it is yet not really beneficial since they lose the acting thus, though with that what joy it would be!] János Erdélyi, "Úti levelek Párizsból," Pesti Divatlap, January 19th, 1845, philosopher and critic, later director of the National Theatre in 1848-49. Also in Maller \& Ruttkay, p. 134-135. 


\section{WEEDING AND PLANTING}

According to Trewin, one of his biographers, Macready "had no regard for the profession he helped to raise. ${ }^{\prime 43}$ However, Macready himself says in his Diary: "Miserable as my profession is, its wretchedness is aggravated by the persons allowed to degrade it." ${ }^{44}$ Fortunately, a well-known oracle, the Oxford Companion to the Theatre sticks to facts more than Trewin does here and concludes: "He [...] made many enemies, particularly by his constant disparagement of the profession which he adorned." ${ }^{45}$

Most of the defects in the colleagues that were the targets of Macready's merciless weeding, in fact, well deserved their fate: in either Covent Garden or Drury Lane, Macready accepted neither carelessly collected riffraff costumes without study, nor indolent and improvised quotations from the author instead of the playtext. When not in a managerial position, he restricted himself to open disdain towards colleagues, letting off steam in his Diary in the shape of frequent sighs, complaints and even more frequent curses. ${ }^{46} \mathrm{He}$ blamed these buffoons of colleagues for the lack of social respect and financial safety which was a painful experience for actors ${ }^{47}$ in the mid-nineteenth century. Constantly worried about the future of his seven children, Macready made desperate efforts to maintain a steady middle-class living on an actor's income that was rather unpredictable both in sum and regularity.

Apparently, he did all he could: "He was the first English manager to insist on full rehearsals, particularly for supers and crowd-scenes, ${ }^{48}$ as even the laconic Oxford Companion registers. As Horne vividly describes it, "he made the supernumeraries act - a mortal labour. He not only multiplied the brood of these 'turkeys,' but he crammed them, and made men and women of them." ${ }^{\prime 9}$ Under the heading of "ensemble acting" however, we certainly should not understand

43 J. C. Trewin, Mr Macready. A Nineteenth Century Tragedian and His Theatre (London: Harrap, 1955), p. 7.

44 Macready, The Diaries, Vol. I, p. 129, dated May 14th, 1834.

45 The Oxford Companion to the Theatre. ed. Phyllis Hartnoll (Oxford: Oxford University Press, 1967), p. 598.

46 One of his recurrent remarks in the Diary: He was "disturbed [...] by the carelessness of the performers" (Vol. I, p. 178). He regularly complains about "ill-disciplined actors" (Vol. I, p. 192).

47 They needed extra income, e.g. American and country tours, to stretch the family purse.

48 The Oxford Companion to the Theatre, p. 598.

49 Horne, Vol. II, p. 116. 
the same as today. Stars like Macready did have their "peaks," but at least not only peaks. With Macready the intention to present a whole character throughout the play finally appeared. To those who expected the leading actor change back into a private person after giving an elevated recital of a "piece" (the word itself is indeed telling) to bow and seek immediate applause, or even to repeat a monologue (e.g. the Curse) as Garrick often did, Macready caused serious disappointment.

Just as Macreądy, Egressy also headed a change in both quality and style. He started his career as an itinerant actor acting in their "singing-crying" 50 declamatory style. The most tender hearted and civilised of critics, even Vörösmarty sends the once respected representatives of the old school off the national stage. ${ }^{51}$ Young Egressy adapted and was soon to set the standards of modern Hungarian acting. He did so by example and also by sharing his views in print. He authored handbooks, A szinészet könyve (1866), A színészet iskolája $(1879),{ }^{52}$ valid ever since, and a good deal of articles. He claimed: "az eddigieknél nagyobb praecisiót 's correctséget nyernének elöadásaink, mi genialitás nélkül is eszközölhetô, ha komolyabban vesszük a színészetet, 's kissé több fáradságot veszünk hozzá magunknak." ${ }^{\text {3 }} \mathrm{He}$ also insisted on ensemble acting implying ensemble rehearsals, a matter initiated by Macready on the early Victorian stage as well: Egressy says, "ne játsszék a' színész mindig magának, hanem az egésznek, a' tárgynak, azaz: segítse motiválni társa' játékát." ${ }^{54}$ An inherently private Englishman, Macready does not go further to educate future actors than the following remark in his Diary: "I never acted Macbeth better, and learned much in this night's performance. Hear this and understand it, if you can, you 'great' young actors!"'55

50 The critic József Bajza described it thus, expressively enough for the phrase to become a technical term.

51 "There was a time when with stately stature and loud voice, that shook if not the viewers then at least the theatre (which not rarely was made from unworthy material), was held as appreciated and as main thing in art. Now the demand of the age has become stricter: people would like to understand for what they applaud." (Vörösmarty 1974: 692)

52 A szinészet iskolája was published posthumous in $1879,1889$.

53 [Our performances would gain greater praecisio and correctness which are achievable without geniality if we take acting more seriously] Gábor Egressy, "Párbeszéd Szebeklébi és Egressy között színészi dolgokról” (1842), Egressy Gábor válogatott cikkei 1839-48, a facsimile edition, ed. Ferenc Kerényi (Budapest: OSZK Színháztörténeti Tár, 1980), p. 5.

54 [The actor should not play for himself but for the whole, for the subject, that is, help motivate his colleague's acting] Egressy Gábor válogatott cikkei 1837-48, p. 6.

55 Macready, The Diaries, Vol. I, p. 236, dated February 1st, 1847. Italics are mine. 
Egressy's suggestions rhyme well with Macready's standards; of which many remained confined in the Diary to the utter delight of future readers, while others were voiced at rehearsals to the utter resentment of colleagues. Egressy's fiery temperament could not stop at the public articulation of his opinion: he responded to the lack of school for actors by founding one. ${ }^{56}$

As it is doubtful that the English star ever heard of Egressy or Hungary, it is time to see how Egressy managed to possess morsels of foreign news and experience. After Anschütz's Lear he was left alone professionally, let alone Vörösmarty's instructive criticisms, thus it must have meant a great deal what he learnt from travellers' accounts.

Having seen Macready and his company in Paris in the winter of 1844-45, János Erdélyi talked, addressing his account directly to Egressy, of the celebrations with which the initiated and illuminated Paris audience greeted Macready. An aesthete, critic and philosopher, Erdélyi immediately reports on the state of the French Shakespeare cult as if it were a special thermometer to measure the development of civilisation and taste.

Then he gives a sensitive account of Macready's and Miss Faucit's electrifying performance and original reading of Othello and Hamlet. Erdélyi found Macready's Othello full of warm colours, his Hamlet loving and highly sophisticated, offering extra material to Egressy. Whether or not Erdélyi is a reliable reporter, nonetheless, he appears to be a credible one. We must believe him when he is touched by and hence stresses Macready's extraordinary talent for depicting gentility and tenderness, suppressed pain, mingled with love and desire, as this ability of Macready had always been mentioned and praised by the English press. Also, Erdélyi's writing about it refers to the fact that these refined touches must have been a novelty for the Hungarians:

Mikor [Macready mint Othello] elmondja, miképp szeretett belé Desdemona, ez nem puszta elbeszélés, hanem a leglángolóbb emlékezet megújulása, boldog szeretôi diadal [...] Harmadik felvonásban, hol Jágó fölkeltvén lelkében a vihart, a féltékenységet; így szól: Látom, hogy észrevételeim nagyon felizgatták kedélyedet. - Egy jotát sem (Not a jot, not a jot!) - felel Othello kimondhatatlan fájdalommal, melyben mind látszik a gyöngéd szerelem Desdemona iránt. ${ }^{57}$

56 The institution opened in 1865 , nearly thirty years after its anticipation.

57 [When [Macready as Othello] tells about how Desdemona fell in love with him, this is not a mere narration, but the renewal of the most blazing/ardent memory, of the lover's happy victory. [... ] In 
The future director of the National Theatre (1848-49), Erdélyi continuously keeps track of both the actor's performance and of the audience's reactions, apparently holding them equally important throughout his report.

Erdélyi's previous experiences, "egy szer a színpad közepérôl hurcolta nyakán fogva, fojtogatva Desdemonát Othello az ágyba [... ] máskor azt is láttam, mint szoríták ki a lelket párnával szegény böl, ${ }^{, 58}$ seem to have stood on the verge of the ridiculous and the primitive, which, we can see, "dashed his spirits" a little. József Bajza, by recalling a very similar scene in 1842, verifies Erdélyi's memories. He must have referred to the very same performance (Lendvay as Othello), not without utter disgust: "Istenért! ne hurcolja többé Othello Desdemonát, és ne fojtsa párnákkal agvon szemünk elôtt, mert ez hajborzasztó." Interestingly, Bajza comes up with the same idea Macready's company was to present in Paris, surely ignorant of the English actors' practice: “A megfojtás az ágykárpitok között mehet végbe, de ne szemünk elött."

This quite Mediterranean practice of dragging and public suffocating which alienated many a Pest-Buda spectator from Othello in 1842 appears to have been a widely spread and widely known scene as Gvadányi wrote an amusing story titled Egy falusi nótárius budai utazása, and later József Gaál was inspired to make a comedy, A peleskei nótárius, out of it. ${ }^{5 i}$ A highly sympathetic spectator, the notary of Peleske on his visit to the theatre rushes onstage only to save poor Desdemona from brutal Othello's enormous black hands. Erdélyi even provokes the spectator by asking, "Csuda-e, ha ilyek láttára irtózik a peleskei nótárius?" ${ }^{22}$ Erdélyi clearly prefers the use of a curtained four-poster bed which offers comfortable privacy to execute the task and Desdemona undisturbed.

the third Act when Iago says, stirring the storm, jealousy in Othello's heart: I see this hath a little dashed your spirits. - Not a jot, not a jot! - Othello replies, full of unutterable pain in which his tender love for Desdemona is apparent.] János Erdélyi, Pesti Divatlap, Maller \& Ruttkay, p. 134.

58 [Once Othello dragged Desdemona by the neck, stifling, from centre stage across to bed, on another occasion I saw when with pillows her soul was pressed out of her.] János Erdélyi, Pesti Divatlap, Maller \& Ruttkay, p. 135.

59 [For God's sake! let us not allow Othello to drag Desdemona and stifle her with pillows to death before our eyes because this is horrid.] József Bajza, Athenaeum, November 22, 1842, also in Maller \& Ruttkay, p. 113.

60 [The choking must take place behind the curtains of the bed, not before our eyes.] József Bajza, Athenaeum, November 22, 1842, also in Maller \& Ruttkay, p. 113.

61 The play was among the first to be staged at the National Theatre (1838).

62 [Should we marvel that the notary of Peleske shudders at such a sight?] János Erdélyi, Pesti Divatlap, Maller \& Ruttkay, p. 135. 
In fact, Macready was merely following the English theatrical tradition which comprises stock props as well as stock stage business. In Macready's study book in which various Shakespeare plays are bound together with Lear, I found a plate on the frontispiece of Othello displaying a large canopy bed with an abundance of curtains, size and shape of a Turkish tent, to provide for the double deaths.

Hence Egressy must have found it vital to widen his own and his contemporaries' horizon: he initiated and then edited a new critical magazine to serve as the compass of theatrical art, taste, and to guide audiences. The magazine called Magyar Színházi Lap managed to survive in 1860 only for a year.

Nonetheless, even this unfortunately short-lived journal furthered the actors' cause. Egressy asked for and received material from contemporary literary celebrities. Beside poems, reviews and theoretical writings he published a brief view on the actors of the English stage sent by Jácint Rónay, Hungarian immigrant from London.

Egressy's London correspondent was in fact an emigrant Catholic priest, former secretary to Kossuth and the first Hungarian Darwinist who spent sixteen years in exile in England between 1850 and $66 .{ }^{63} \mathrm{~A}$ member of the British Association for the Advancement of Science, ${ }^{64}$ Rónay regularly read about and attended the London theatres collecting material for his reports. His articles being well-informed, attentive and remarkably impartial, Egressy wanted Rónay to provide a series on English actors for his magazine. "Kean Edmund életrajzát alig várom. Bármily hosszúra terjedne az, jogos helyet fog lapomban foglalni. [... ] És ha Kean-nel készen leszünk, nem lehetne-e aztán Shakespeare életére is gondolnunk?" ${ }^{55}$ Not only did Rónay write Edmund Kean's and Shakespeare's biographies, but he sent Egressy the lives of Charles Kean and Macready as well.

63 Rónay's exile in England: 1850-66. A selection of his Diary incorporating these years was first published in 10 copies according to Dávidházi, but was re-selected and re-published in 1996.

64 Dávidházi, p. 209. In England Rónay taught Kossuth's sons, while back in Hungary he taught Rudolf, heir to the Habsburg throne (1871-72) and Princess Mary Valery (1875-83).

65 Jácint Rónay, Napló (Válogatás), eḍ. György Hölvényi, METEM könyvek series 13 (Budapest \& Pannonhalma, 1996), p. 258. Rónay kept some of Egressy's letters to him, the one quoted above is from among them. [I can hardly wait for the biography of Edmund Kean. No matter how long it will extend, it will receive its rightful place in my magazine.[...] And if we are done with Kean, could we think of Shakespeare's life then?] Rónay's study on Shakespeare appeared in the Appendix in Vol. VIII of his Diary published in only ten copies. 
Even if the book, ${ }^{66}$ compiled from the earlier papers came out in 1865, the year preceding Egressy's death, on the basis Egressy's thoroughness, interest and zeal we might well assume that these were read by the Hungarian star.

The friendly tone Rónay uses in Macready's biography is characteristic throughout the whole book, however, it does not indicate his partiality. His background as a scholar, natural scientist and cleric served Rónay well: his statements are moderate, factual and argumentative. All his information coincide with the other sources, e.g. Macready's own writings, Erdélyi's letters, or even a French journal which collected the contemporary French response to Macready's 1844-45 tour in Paris. Hence the citations below (unfortunately none about his King Lear) will not only stand there to embody what Egressy in fact knew of Macready at the time, but necessarily they will summarise the features that relate Egressy to the English star.

"Tanulni nem szünt meg soha," wrote Rónay, "de játékát szigoru, ingatlan elvek intézték; ezért haladása következetes volt. [... ] Játékban a következetesség, szorgalom nélkül nem is képzelhető, s Macready feltűnőleg szorgalmatos volt." The description might fit Egressy, without any changes: all his books, articles and personal example, strict demands of praecisio and industriousness echo Rónay's words. He continues, “szerepe minden szaván, játéka minden mozdulatán, kezdettôl végig keresztül haladott akkor is, midoón kedveltebb hőseit százszor ismétlé." ${ }^{67}$ However, not only does the latter statement betray the actor's honest self-discipline. It also reveals the fact that he would not have been contented with giving a number of "good pieces of acting" a night: just like Egressy, he insisted on acting a complete character, a round human being, each time building up the psychological background for the figure. It seems, no one questions the work Macready invests in characterisation, now from a French source: "Le talent de Macready réside dans l'étude et la méditation, dans le lent perfectionnement de

66 Jellemrajzok az angol színvilágból: Kean Edmund, Macready Vilmos, Kean Károly. [Portraits from the World of the English Stage. Edmund Kean, William Macready, Charles Kean]. Pest, 1865.

67 [He never gave up studying, but his acting was directed by strict, unchanging principles thus his progress was consequent [...] Consequent thinking cannot exist without industriousness in acting, and Macready was outstandingly industrious. He went through each and every word and gesture of his roles, from the beginning to the end, even when he repeated one of the favourite parts for the hundredth time.], Rónay, p. 119. 
l'exécution" ${ }^{18}$ the La revue sums up. On the occasion of the 1844-45 Paris tour, the Le Constitutionnel stated that "l'acteur se montre sur la scène tout pénétré de l'esprit de son rôle, tout imprégné du puissant génie de Shakespeare." ${ }^{69}$ The latter remarks further assert the fact that Macready was not keen on delivering the traditional "points" but re-presented the imagined character on stage.

"Macready nem puszta szenvedélyböl, hanem meggy őződésből volt színész;" argues Rónay, "azért a színészetet nem csak saját diadalaiban, hanem általános vívmányaiban is szereté, s ha küzdött, hogy nevét a feledésböl kivivja, küzdött azért is, hogy pályatársainak tisztességes állást biztosítson, hogy a színészetet magasra emelje." ${ }^{\text {"0 }}$ Although Rónay's empathy might be felt here, one cannot really deny the truth in his sentences. Macready took pains to find a new and respected place for the histrionic profession in the middle class, an effort Egressy shared with Macready.

\section{THE GREEN CLOTH ${ }^{1}$}

Thus not lacking encouragement from and being surrounded by the most learned men of the time, hence guaranteeing his theoretical background and promoting his popularity, Egressy was able to raise considerably the renown of his profession and to produce, in his most timely art, something that would be memorable in the future. Around Macready's person a quite similar circle developed and the mutual co-operation and respect between the artist of the stage and the artists of letters bore fruit: the actor's profession was not the same as when Macready started his career. In his Shakespearean restorations what once, in the age of Charles Lamb seemed impossible to reconcile, theory and practice, reading and acting met. Shakespeare could only have benefited from all this: the popularity of

68 [Macready's art lies in study and thought, in the slow perfection of the execution], "William Charles Macready et les comédiens anglais à Paris (1844-45)," La revue des lettres modernes, Nos. 7475 (1963), p. 16.

69 Le National: [throughout the scene the actor seemed to be entirely penetrated by the spirit of his role, entirely impregnated by the great genius of Shakespeare]; La revue, p. 19.

70 [Macready became an actor not because of sheer passion but out of conviction; hence he not only liked the acting profession for his own successes but in general too, and if he struggled to lift his name from oblivion he struggled for his fellow-actors as well, to provide them with proper jobs and for the elevation of the profession.], Rónay, p. 113.

$71 \mathrm{~A}$ quote taken from the end of the promptbook prepared by Macready for his partial restoration in 1834, surprisingly preserved in the Bodleian Archives. 
the actors conveyed the merits to the wider public. If nothing else, the cult, learned respect that had preserved Shakespeare's plays grew. Egressy managed to play Lear fifty-six times while Macready in his longer career gave it eight more times. $^{72}$

Both acting versions of King Lear were milestones in their own tradition, which of course, even the enthusiastic recorder of their histories admits, were only there to be surpassed. However, doing so was not very easy. Charles Kean and Irving built their spectacular Lears on Macready's only after his retirement; and only Egressy's death could put an end to the career of a text in which, incidentally, only his part was in iambic meter. Vörösmarty's powerful and tragically instrumented translation of 1855 had to wait for fifteen years until the actor's memory in that well-trained audience of Egressy and his literary friends would fade. Even after Vörösmarty's translation was finally billed at the National Theatre in 1870, four years after Egressy's death, the new text often got overwritten by Egressy's in the promptbook, in individual parts and personal memories.

72 Egressy's data from Staud, p. 115, Macready's data from Archer, p. 203. 